\title{
Pancasila Literacy to Build Insightful Citizenship Civilization Environment in the Industrial Age 4.0
}

\author{
Bali Widodo ${ }^{1, *}$, Suwarma Al Muchtar ${ }^{2}$, Endang Danial $\mathrm{AR}^{3}$
}

\author{
${ }^{1}$ Institut Teknologi Nasional Bandung, Indonesia \\ ${ }^{2,3}$ Universitas Pendidikan Indonesia, Bandung, Indonesia \\ ${ }^{*}$ Coressponding author: baliw@itenas.ac.id
}

\begin{abstract}
Many factors can cause damage and environmental pollution. Natural damage can be caused by human factors. Human population and environmental problems cannot be separated. Human needs for food, fuel, shelter, and other needs as well as the increase in domestic waste have the potential to cause damage and environmental pollution. Environmental problems can also be caused by technological advances. Many industrial wastes contain toxic and hazardous materials whose waste is disposed of in rivers, although technology is also needed to overcome environmental problems. This destruction and pollution of the environment can be prevented by instilling the values of Pancasila in everyday life. This study aims to examine the strengthening of Pancasila literacy in learning Citizenship Education as character education to build an environmentally sound civic civility. This research is conceptual research with a library research method, namely collecting data from research reports, scientific articles, or other sources relevant to the topic. The results of the analysis of this discussion explain that citizens who have Pancasila literacy have a concern for maintaining and preserving a good and clean environment. The implications of the research are expected to be able to shape the character of students who are Pancasilais and have a concern for the environment, and the results of this study are also expected to be able to answer issues regarding damage that arise due to the citizens' lack of understanding of environmental insight.
\end{abstract}

Keywords: Citizenship Civility, Environmental-Care Character, Pancasila Literacy.

\section{INTRODUCTION}

The environment is one of the responsibilities of the state in creating the welfa re of the Indonesian people. Good environmental management by humans will have an impact on good interactions between humans and nature. Therefore, in accordance with the legal basis of Article 57 paragraph (1) of Law No. 23 of 2003 concerning the protection and management of the environment there is an arrangement of efforts to preserve the environment.

So that the legal basis above, becomes a way of life for the Indonesian people to be able to love, protect, manage and preserve their environment. Therefore, in this case the government has a role in creating control to create citizens who obey a rule.

But back again to human nature which is never satisfied, that technological or industrial developments do not always have a good impact on the development of human life, but can also cause a number of damage to the ecosystem of the human environment, for example the progress of transportation. [1]
Then the other factor is that Indonesia is a country that is vulnerable to climate change which results in damage and availability of water, this factor is usually referred to as a natural factor (homeostasis) [2]

So that the estuary of environmental pollution is due to a development that does not consider the environmental capability factor. Therefore, it will have an impact on pollution. Pollution is a damage that can occur due to nature and due to human actions, this human action depends on how the pattern of habits he lives, the pattern of life that leads to the character of the environment. [3]

Therefore, in this study it is very important to do in assessing the character of citizens who care about the environment. Because humans have the greatest influence and impact on the destruction of the environment. This is due to the increasing mobility of human growth, this growth needs to be balanced with the ability of nature to accommodate so many human resources.

So, in this case, to answer the challenges above, it is necessary to build a good interaction between nature 
and humans, namely by building a perspective, understanding concepts about the environment that have an impact on the environmental character of citizens. [4]

Then apart from that, other things that can be done to minimize the occurrence of environmental damage are the need for legal protection that can be heeded as an environmental law instrument to manage the citizens' environment. The government must be able to guarantee environmental sustainability for the next generation, the government can supervise and monitor the use of the environment by citizens [5]

Furthermore, in addition to the lack of human awareness as citizens who can maintain a gift from God Almighty, this is also caused by a lack of ability to understand environmental concepts, and also a lack of ability to read, understand and implement Pancasila values in life to preserve sustainability. environment.

Then, to improve the order of people's lives, it will depend on the reading quality of citizens. So that in order to achieve a goal that is expected to be in accordance with the goal of achieving a better life, then that goal must be equipped with literacy skills.

So that the quality of a citizen depends on the level of reading ability, reading habits and culture of the community which can create a participatory society, have the ability to access information and knowledge. In accordance with the basic needs of life that lead to the world of information or 4.0.[6]

Literacy ability is a very important competency in building a good human civilization, because it always follows the development of culture created by humans. Therefore, because culture is dynamic, the meaning of the development of literacy skills needs to be expanded not only to be developed in reading skills, but also able to be applied and applied in everyday life. [7]

Therefore, in accordance with the purpose and urgency in this study that build Pancasila literacy, the Pancasila literacy ability can be developed through the role of civic education in schools. So that if this can be achieved, there will be the formation of citizens who have a culture that leads to environmental habits that arise in them, and considers that the environment is a unity within themselves that needs to be maintained and preserved.

To accompany technological developments that are increasingly skyrocketing, the abilities and competencies of teachers and students need to be updated. To achieve the competence of Pancasila literacy, it will depend on Civics learning based on Pancasila literacy which can develop the civilization of citizens who are environmentally sound.

This series of goals, if achieved properly, will become a beautiful vision that can produce outputs of citizens who have environmental insight, not only understand concepts, but are able to apply them in daily life in accordance with the characteristics of literacy in the information age 4.0.

So according to the purpose of this study, the formulation of the problem in this study is to determine the literacy of Pancasila to build a civic civilization that has environmental insight in the 4.0 era.

\section{THEORETICAL REVIEW}

\subsection{Civics as Value Education (Civic Virtue)}

The existence of the achievement of civic competence which has the aim of creating civic knowledge, civic skills and civic disposition, namely knowledge, skills and civic character. So that this competence leads to the development of the character of citizens to create ecological citizenship. Furthermore, because of the strategic picture, the development of these competencies becomes a means to construct citizenship that has environmental character. So that Civics becomes one of the means to carry out character education because Civics is also a subject that carries out the vision of education, values and attitudes. [8]. Efforts to build character through civic education are planned efforts carried out by schools as educational institutions that carry out the vision of creating citizens who have the personality of the Indonesian nation. The implications of character education through environmental movements in the community make people become citizens who have knowledge, are smart in empowering existing resources such as empowering waste banks, waste disposal activities in place, productive planting, bakto work and managing organic waste, utilizing waste for recycling [9]. So to strengthen the opinion above, value education is an educational process to shape human personality as a person who has human values to respect, respect and shape human beings as a whole. [10]. So this statement is part of the embodiment of Pancasila in all the points of Pancasila which are used as guidelines for the behavior of the Indonesian people.

Building students' awareness of human values is a shared vision of value education and civic education, which can be seen from the object of study these two elements are the same as building the character and personality of the moral Indonesian nation. Therefore, the character developed in this study is the character of caring for the environment through strengthening Pancasila literacy by citizens in the information age so that the creation of citizens is called ecological citizenship. Citizens as a civic education effort to provide value education through Pancasila literacy in Civics subjects that have been integrated with environmental education will give birth to citizens who participate actively in shaping their moral awareness. This is in accordance with the theory [11] who said that the provision of value education as a manifestation of ecological education in school learning is believed to be able to train students to have a character that is obedient 
and obedient to values, then Nash added that everyone has values for himself, so that through inculcating environmental character in students helps the formation of responsibility students for themselves and their environment. [11] also added in his findings that this is referred to as moral identity, which is a form of moral awareness by humans who view and treat nature like humans who have the right to life. So that the above findings are expected to lead to the existence of Technological Developments in the 4.0 era which aims to improve the quality of human life, but it does not mean that it has an impact on environmental damage and pollution, this is controlled and controlled by the existence of a moral identity created by humans as creatures who live side by side with nature.

Furthermore, to achieve the implementation of civic education as value education, that this goal is the basic goal of citizenship education, namely to make citizens as moral and valuable citizens in accordance with the values of Pancasila. Therefore, the urgency in this study is to achieve the goal of civic education, namely to create intelligent and characterized citizens. Then the role of the teacher is needed in formulating learning strategies in which Pancasila literacy and character education have been integrated to foster environmental care characters in citizens. This research needs to be done, because it is a shared responsibility to make us human beings who can maintain the integrity and grace of nature given by God Almighty, as the embodiment of the first and second precepts. Therefore, a technological advancement is a direction of mobility that cannot be avoided, its progress is also greatly enjoyed by the nation and the current generation. But as a tribute to nature, this technological progress should not be destructive but must be heeded and preserved. Therefore, through this research, it is hoped that it can shape the character of citizens who care about the environment in the 4.0 era, which is an era where everything is done based on data and digital sources. Furthermore, basically the essence of civic education is part of value education, which aims to give birth to citizens who have virtue values in themselves, namely humans as human beings who not only have intelligence in thinking but also have intelligence in behavior, especially caring for others, especially for their environment.

\section{METHOD}

This research uses a qualitative approach with a literature study method. The qualitative approach in this research is the type of data collection using secondary data, which is data that provides indirect data to the researcher. [12]

The method that will be used in this research is the Library Research/Study Literature method. Namely by using data analysis: selecting, simplifying, reducing data obtained from various sources, presenting data (short description), verification and conclusion (checking and interpreting data from the literature) [13] Library research as well as utilizing library resources to obtain research data. Library research limits its activities only to library collection materials without the need for field research. Thus, literature research is used to explore, examine, and analyze various relevant references to be used as the basis for theories and scientific literature related to the context under study.

\section{RESULTS AND DISCUSSION}

\subsection{Pancasila as a System of Ethics}

To develop the literacy skills of Pancasila according to the results of research by researchers, one of them is the formation of learning media which has an important role in achieving the literacy abilities of Pancasila citizens.

Citizenship education learning media that are used if they are innovative, will become a learning tool that can guarantee students' Pancasila literacy and will grow into Pancasila insights that have an impact on the formation of attitudes and character.

Therefore, returning to the goal of creating citizens who have literacy skills that can be internalized by Pancasila values in everyday life, it is necessary to do this through structured and planned Civics learning.

So the first step taken by the teacher in this case is to integrate the value of digital literacy into all learning components and carry out learning activities that lead to students' literacy skills not only reading and writing but also being applied in everyday life

The purpose of Pancasila literacy in this case is to form, nurture and educate the character of citizens in accordance with the reflection of the personality of the Indonesian nation, namely citizens who have intelligence in being responsible for themselves and their environment. [14]

Pancasila literacy is a guide system for citizens to maintain the values of Pancasila to continue to live and develop in the midst of the hustle and bustle of the impact of the decline in the moral and character of the nation in this 4.0 era. [15]

So in this case there is a research conducted by Desi Karolina who is a researcher on the Relationship of Pancasila Literacy in Characterized Indonesian Education. This research results that character education is the most appropriate bridge through Civics to provide Pancasila literacy skills as young citizens. So that the demands of Civics learning can make character education a powerful strategy to develop learning that trains students' ethics and morals through the learning process. The learning can contain videos, audio or short films as a manifestation of era 4.0 learning to give the impression of Pancasila values on students' personalities [16] 
While the difference in this study is that citizens who have the ability in Pancasila literacy will build citizen awareness in the environment, so that Pancasila literacy here is expected to strengthen the environmental character possessed by citizens. That is, with Civics learning efforts in schools to achieve a civilization of progress in the implementation of learning in the 4.0 era.

Thus, Pancasila literacy must be presented creatively that describes the idea of nationality. So this is in accordance with the statement which says that the literacy skills of citizens will lead to the development of language skills, the ability to understand material, and the ability to think. [17]

Furthermore, to strengthen the above statement, James W Potter in his theory of literacy said that literacy is a media device as a tool to actively empower oneself and convey messages. Then James continued that literacy is a series of information literacy that aims to control an individual against deviant actions [18]

Furthermore, through the explanation of the theory above, it leads to literacy teaching an individual to have the ability to analyze messages and information that can provide a sense of responsibility and a good response when faced with a problem. [19]

Thus, the literacy ability of Pancasila will be the best guideline for citizens through learning civic education in creating ethics and character to care for the environment, the literacy skills possessed by citizens will help citizens to have environmental intelligence.

The literacy ability of Pancasila citizens will also lead students to have the ability in environmental literacy, based on the concept of understanding through literacy skills will lead to environmental competencies such as the formation of knowledge, the formation of actions and strategies that can be taken if students are faced with environmental problems. This competence is referred to as the citizen's ecological competence, namely the intelligence of citizens in responding to environmental problems [20]

Through the process of cultivating the values of Pancasila as the embodiment of the first precept, Belief in One Supreme God, and the second precept, just and civilized humanity. It can shape the ethical values of citizens as a form of creating awareness that the environment is a gift that must be preserved by humans.

Pancasila literacy skills will form environmental awareness, citizens' environmental literacy in accordance with the ecological ot environmental theory by [21] which says that the ability to understand students' environmental concepts will help achieve the country's goals in maintaining the integrity of the human environment, therefore the environmental or ecological literacy abilities of citizens are not only limited to their knowledge. But also on the ability to make the results of environmental literacy a habit within him [22]
The achievement of Pancasila literacy skills through citizenship education will help achieve the formation of ecological citizenship. The formation of citizens who care about the environment based on Pancasila values which are used as an ethical system in the implementation of daily life. so that these citizens become citizens who are responsible for their daily environmental problems.

\subsection{The formation of environmental insight}

The formation of environmental insight in 4.0 requires a very innovative strategy for delivering environmental material. Therefore, it is necessary to have the skills and understanding of teachers and students about the concept of the environment to create a balance between technological progress and the use of natural resources [23]

The achievement of environmental character through Pancasila literacy in Civics learning will indirectly lead to the formation of ecological citizenship. So that in this case it also leads to strengthening Pancasila literacy as well as a process of inculcating character education which is also part of value education.

In accordance with technological developments which also lead to the development of the world of education, transportation and industry, there is a need for human needs with technological capabilities, as in theory, "if a citizen has environmental intelligence, then he will form behavior that can utilize natural resources according to their needs without having to destroy the ecosystem and think about the next generation". [21]

Furthermore, in the formation of environmental insight, according to the ecological theory by Hawley, it is known as the process of developing an ecological human model, namely human behavior that is ecosystem complexity, namely its characteristics such as 1) human behavior that cannot be separated from the environmental context, 2) human interaction with the environment that produces mutualism relationship, 3) the formation of environmentally conscious knowledge [24].

So that in the efforts of schools and the government in creating a society that has environmental insight, it is necessary to carry out plans for implementing formal education in schools so that teachers can play a maximum role in fostering students who have character and are environmentally friendly. [25]

Next in research [26] it is said that "the development of environmental learning models based on practices in the community will help shape students' ecological or environmental insights". so that in this case a learning device that has been systematically integrated is needed which is an internalization of the values of environmental education.

So this is reinforced by the research conducted by Budimansyah and Prasetyo who said that to produce 
schools and school residents who have environmental insight, learning is not only charged with cognitive abilities or limited to concepts, but also must be developed into an action. So that in this study pioneered the formation of an environmental protection community. [4]

Furthermore, to achieve the competence of students who have environmental insight, schools need to implement a curricular system based on the environment. Namely by integrating the value of environmental education through civic education in order to create citizens with character and care for the environment.

Environmental education that is oriented towards environmental insight education through civic education is a responsibility that must be carried out by teachers and schools as the main actors to carry out the vision of environmental conservation through education.

So, according to Sumarwoto, [27] said that "the process of integrating environmental education in the curriculum will bring about changes in student behavior. so that this change will also have an impact on student behavior in interacting with their environment.

Based on Fauzi's research on Environmental Education that "subjects that are integrated with the purpose of environmental education in it can contain social characters such as honesty, discipline, responsibility, care, tolerance and practice social interaction skills with the social and natural environment. This competency is believed to be able to train students' awareness of the surrounding environment [28]

Therefore, teachers as educators must be able to develop indicators of environmental learning for students, such indicators as having the dimensions of a physically and mentally healthy attitude, living healthy in the school and community environment, and having the character of maintaining and preserving the environment. [28]

Then based on theory [29] who said that "basically protecting the environment is a complex problem that needs to be handled in a structured and systematic way, one of which is through the educational process". So that the environment-based curriculum must contain environmental management and protection plans to form students' environmental understanding and insight.

The purpose of integrating environmental insight material into Civics subjects is to help train students' independence in facing the challenges of environmental problems in everyday life.

When viewed from the 4.0 era, it indicates the development of the world of education on the need for information that is global in nature which will have an influence on the phenomenon of globalization and global trends such as the global economy, technology and communication, and population environment. [30].

So the impact of this era is the development of the environment and human population. So that environmental damage can be caused by industrial progress and sophistication which results in exploitation of the environment. Because this continues to be done and there is continuous exploitation, the environmentalism movement has emerged to protect environmental sustainability from various kinds of pollution and damage. [31].

So in the book it is also added that the movement is a movement to build awareness of the environment which aims to increase people's ecological awareness which is called ecoliteracy. [31].

Then, based on the research conducted by Rondli and Khoirinnida on Ecoliteracy-Based Citizenship Education Learning: Ecological Citizenship Reconstruction Efforts. That this research recommends sustainable development in the 21 st century through the implementation of education that is integrated with environmental issues. Civics learning as ecoliteracybased education that aims to grow individual awareness and knowledge about the environment.

Through this research, it is explained that the concept of ecoliteracy through research conducted that citizens' understanding of the urgency of global ecological awareness will help create a balance between the needs of the world community and the quality and capacity of nature to meet human needs.

Furthermore, the development of the 4.0 era was marked by the development of information and industrial needs in Indonesian life. So that it also has an impact on human work needs which continue to increase in a complex manner, besides that this development also marks the human need for life that is carried out based on digital activities, and is multitasker.

So that the relation with environmental education is understanding in developing environmental insight which also has environmental competence, namely understanding the concept of environmental knowledge, and being able to apply it in daily life in accordance with theory. [21]

\section{CONCLUSION}

Citizenship education based on Pancasila literacy can improve the civility of citizens in environmental insight. The development of Pancasila literacy is developed through the process of integrating the values of environmental education into Civics learning tools. Pancasila literacy competence can form environmental insight in citizens. So that the formation of the character of caring for the environment in citizens or 
what is known as ecological citizenship. This environmental care character is integrated into value education through civic education in schools in order to make citizens as citizens who have environmental insight and ecological intelligence in utilizing natural resources, and considers that the environment is a gift from God Almighty that should be preserved and is a practice. in the first and second terms. Strengthening environmental insight through Pancasila literacy in Civics learning helps make citizens a citizen who follows civilization and technological mobility that leads to the advancement of the information era 4.0. environmental insight developed through Pancasila literacy makes him an active and independent citizen in solving environmental problems, and able to utilize resources such as recycling waste. This ability is referred to as citizen environmental intelligence. The implementation of citizenship education based on Pancasila literacy makes citizens as citizens who have moral awareness or moral identity, namely assuming that the environment is a part of themselves that must be preserved for its beauty.

\section{ACKNOWLEDGMENT}

The research is a grant from the National Institute of Technology. The authors would like to express sincere appreciation for all support provided.

\section{REFERENCES}

[1] Feriandi, Yoga A. Upaya Perlindungan Lingkungan Perspektif Konstitusi dan Pendidikan Kewarganegaraan. Jurnal Pancasila Dan Kewarganegaraan, $\quad J I \quad 3 \quad$ (2). http://journal.umpo.ac.id/index.php/JPK/article/view/9 76/790, 2018

[2] Ma'ruf, A. Aspek Hukum Lingkungan Hidup Dalam Upaya Mencegah Terjadinya Kerusakan dan Pencemaran Lingkungan Hidup di Indonesia. Jurnal Fakultas Hukum Universitas Slamet Riyadi, Vol.XXIII,. https://doi.org/http://dx.doi.org/10.33061/1.jwh.2018.2 4.1.2997, 2018.

[3] Erwin, M. Hukum Lingkungan Dalam System Kebijaksanaan Pembangunan Lingkungan Hidup, Refika Aditama, 2008.

[4] Dwi Mustikarini, I., \& Feriandi, Y. A. Konfigurasi Pendidikan Kewarganegaraan Ekologi Perspektif sosio-kultural (Gagasan Pembentukan Pendidikan Kewarganegaraan Kontium Maksimal di Indonesia). Pancasila Dan Kewarganegaraan, 5 nomor 2, 54-64. https://doi.org/10.24269/jpk.v5.n2.2020, pp54-64, 2020.

[5] Herlina, N. Permasalahan Lingkungan Hidup dan Penegakan Hukum Lingkungan di Indonesia. Jurnal Ilmiah.Fakultas Keguruan Dan Ilmu Pendidikan, 3 No 2 .

https://doi.org/http://dx.doi.org/10.25157/jigj.v3i2.93, 20015.

[6] Friantary. BUDAYA MEMBACA SEBAGAI UPAYA PENINGKATAN KUALITAS HIDUP MASYARAKAT. Disastra: Jurnal Pendidikan Bahasa
Dan Sastra Indonesia. https://doi.org/https://doi.org/10.29300/disastra.v1i1.14 85, 2019.

[7] Mustofa, M., \& Budiwati. Proses Literasi Digital Terhadap Anak: Tantangan Pendidikan Di Zaman Now. Jurnal Kajian Informasi Dan Perpustakaan, 11 (1), 114 https://doi.org///doi.org/10.21154/pustakaloka.v11i1.16 19, 2019.

[8] Winataputra, U.S., \& Budimansyah, D. (eds). Pendidikan Kewarganegaraan dalam Perspektif Pendidikan Untuk Mencerdaskan Kehidupan Bangsa. Widya Aksara Press, 2016.

[9] Prasetyo, \& Budimansyah, D. Warga Negara dan Ekologi: Studi Kasus Pengembangan Warga Negara Peduli Lingkungan dalam Komunitas Bandung Berkebun. Jurnal Pendidikan Humaniora, 4 (4), $177-$ $186,2016$.

[10] Komalasari, K., \& Saripudin, didin. Pendidikan Karakter, Konsep dan Aplikasi living Values education (Sapriya (ed.)). PT. Refika Aditama, 2017.

[11] Nash, T. H. Lichen Biology Second Edition. Cambridge University Press, 2018.

[12] Sugiyono. Metode Penelitian Kuantitatif Kualitatif dan $R \& D$. Bandung: Alfabeta, 2006.

[13] Nazir, M. Metode Penelitian. Ghalia Indonesia, 2014

[14] Budimansyah, D. Penguatan Pendidikan Kewarganegaraan Untuk Membangun Karakter Bangsa. Widya Aksara Press, 2012.

[15] Budimansyah, D. dan S. K. PKn dan Masyarakat Multikultural. Pendidikan Kewarganegaraan UPI, 2018.

[16] Karolina, D. Hubungan Literasi Pancasila Dalam Pendidikan Indonesia Yang Berkarakter. Pendidikan $\begin{array}{lllll}\text { Tematik, } & \text { Vol. } & 2 & \text { No, } & 2019 .\end{array}$ https://siducat.org/index.php/jpt/article/view/207

[17] Nurjanah, E., Rusmana, A., \& Yanto, A. Hubungan Literasi Digital dengan Kualitas Penggunaan EResources. Entera Pustaka: Jurnal Kajian Ilmu Perpustakaan, Informasi Dan Kearsipan, 2017. https://doi.org///doi.org/10.14710/lenpust.v3i2.16737

[18] Potter, W. J. Media Literacy 4th Edition. In University of California, Santa Barbara. Los Angeles: Sage Publications, 2008.

[19] Trianto, A., Kurniawan, H., \& Suryanto. Literasi Media dalam menanggulangi berita hoax (Studi pada pelajar SMKN 4 Bekasi dan Mahasiswa AKOM BSI, Jakarta). Jurnal Abdimas BSI, 1 (3), 416-423, 2008.

[20] Palmer, J. A. Environmental Education in the 21st Century: Theory, Practice, Progress and Promise. Routledge, 2015.

[21] Dobson, A. Environmental citizenship: towards sustainable development. Sustainable Development, 15(5), 276-285, 2007.

[22] Feriandi, Y. A. Upaya Perlindungan Lingkungan Perspektif Konstitusi dan Pendidikan Kewarganegaraan. Jurnal Pancasila Dan Kewarganegaraan, 3(2), 28-35, 2018.

[23] Muhaimin. Manajemen Pendidikan Aplikasinya Dalam Penyusunan Rencana Pengembangan Sekolah/Madrasah. Kencana Prenada Media Group, 2015.

[24] Hawley, T. S. Flow Cytometry Protocols. Humana Press, Inc, 2009.

[25] Sapriya. Pendidikan IPS. Remaja Rosdakarya, 2015.

[26] Jagers, S, C. In search of the ecological citizen. Environmental Politics: Taylor \& Francis. 18 No 1. 
https://doi.org/10.1080/09644010802624751, 2014.

[27] Masruri, M. Pendidikan lingkungan hidup. Yogyakarta University Press, 2015.

[28] Setyobudi, F. Pendidikan Lingkungan Hidup di SMP Negeri 3 Kebumen Jawa Tengah. Jurnal Pendidikan Ilmu Pengetahuan Sosial Indonesia, 5 No 1., 2018. https://doi.org/https://doi.org/10.21831/jipsindo.v5i1.2 0180

[29] Curtin. The Miopia. Philadelphia Harper \& Row, 348381, 2014.

[30] Wahab, Abdul, \& Sapriya. Teori dan Landasan Pendidikan Kewarganegaraan (riduwan (ed.); 1st ed.). PT. Alfabeta CV, 2011.

[31] Kalidjernih, F. Puspa Ragam Konsep dan Isu Kewarganegaraan. Widya Aksara Press, 2011. 